P. 558. The Faraglione Rock near Capri is not blackish.

P. 565. The Amphisbænidæ are represented on the map as occurring all over Africa; but none are known from north of $12^{\prime}$ lat. N. except the Mediterranean forms confined to the Atlas and the territory between it and the sea.

P. 644. The range of the Crotalinae extends to Celebes (Lachesis wagleri).

In matters of nomenclature, some inconsistency is displayed in the termination of the names of orders and suborders, and the use of the term "Sauria" for a group embracing lizards and snakes is unjustifiable.

The illustrations are for the greater part original, and many are actually taken from living specimens. So great a training is required to depict properly the attitudes of any class of animals, and especially the often mysterious-looking creatures which form the subject of the book under review, that only artists who have made a speciality of it can be expected to furnish nearly faultless work, which even then may be spoilt to a certain extent, so far as technical details are concerned, through the intervention of the engraver if, as in the present case, his services have also to be enlisted. It will, therefore, not be unnatural if an expert may find fault with a few of the illustrations in this book. For instance, Fig. 23 represents a difference between the heads of the male and female crested newt which does not really exist ; Fig. $3 \mathrm{I}$ shows Bombinator igneus with the eyes much too far apart, Fig. 91 a Tionyx with azygous frontal bone, and Fig. 103 a ventral view of the hand of Ptychozoon with the inner finger longer than the outer, which is just the reverse of nature. But all the figures are marked by a freshness which makes up for any shortcomings, and many may be pronounced as exceptionally good.

In concluding the review I would express the opinion that by this handsome volume a very important addition to science has been made ; that the beautiful illustrations, together with the clear and charming accounts of the lifehistories which it contains, will do much to popularise the study of a rather neglected section of zoology ; and that lovers of Reptiles, of which there are more than one generally thinks, will feel that the new knowledge imparted to them emanates from one who is thoroughly in sympathy with their enthusiasm.

G. A. Boulenger.

\section{THE FORTHCOMING MEETING OF THE BRITISH ASSOCIATION.}

$\mathrm{N}$ the two articles which have already appeared (May 23 and July 18) upon the meeting of the British Association, to be held at Glasgow on September I I-I8, the general arrangements made for the scientific and social pleasures of the members have been described. It is now possible to give an epitome of the programme of the meeting and a forecast of the work of the sections. The sections do not meet on September II and September 19, but on all intervening days.

\section{Epitome of Programme.}

Wednesday, September I I.-President's address in St. Andrew's Hall.

Thursday, September 12.-Conference of delegates of corresponding societies; inauguration of new anatomical buildings at the University, and the opening of the museum in connection therewith; reception and conversazione in the City Chambers, by invitation of the Lord Provost and Corporation of Glasgow.

Friday, September I3.-Garden party at Overtoun, Dumbartonshire, by invitation of the Lord and Lady Overtoun; lecture in St. Andrew's Hall, by Prof. W. Ramsay, F.R.S., subject: inert constituents of the NO. I66o, vOL. 64] atmosphere ; smoking concert in Berkeley Hall of St. Andrew's Halls.

Saturday, September I4.-Excursions; lecture to artisans in St. Andrew's Halls, by Mr. H. J. Mackinder, subject : the movements of men by land and sea.

Sunday, September I 5.-Official sermon in the Cathedral, by the Rev. Pearson M'Adam Muir.

Monday, September I6.-Garden party in the Botanic Gardens and Queen Margaret College, Glasgow, by invitation of the Lord Blythswood, president of the Glasgow Philosophical Society, and Lady Blythswood; lecture in St. Andrew's Hall, by Mr. Francis Darwin, F.R.S., subject : movem ents of plants.

Tuesday, September 17.--Special visits to public works ; conference of delegates of corresponding societies; conversazione in the Exhibition Buildings, by invitation of the president, the chairman and the executive council of the Glasgow International Exhibition Association, I90I.

Wednesday, September I $\delta$.-Concluding general meeting; excursion to Paisley and luncheon in the Town Hall, by invitation of Sir Thomas Glen Coats, Bart.; reception and conversazione in the galleries of the Royal Scottish Society of Painters in Water Colours, 153, Sauchiehall Street, by invitation of the president (Sir Francis Powell, P.R.W.S.) and the council; "at home" in the Art Club, by invitation of the president (Mr. J. E. Christie) and the committee of the Glasgow Art Club; reception and conversazione in the Glasgow School of Art, by invitation of the chairman (Mr. James Fleming) and the governors ; reception and conversazione in the galleries of the Royal Glasgow Institute of the Fine Arts, by invitation of the president (Sir John Stirling-Maxwell, Bart., M.P.) and the council of the Institute; annual inspection and dinner of the Clyde Navigation Trustees, to which a selected number (probably thirty) of members of the British Association will be invited; dinner by the Faculty of Physicians and Surgeons to a selected number of the medical members of the British Association.

By kind permission of the owners, a large number of shipbuilding yards, public works, \&c., in Glasgow and district will be available to the inspection of members during the meeting. Details as to days and times are given in a special handbook and guide that is being prepared by the local committee.

In addition to the information given in NATURE of July i 8 with regard to the sectional meetings, the following provisional programmes of sections have been received.

The president's address to Section B (Chemistry) will be on the position of British chemistry at the dawn of the twentieth century. In this address Prof. Percy Frankland, F.R.S., will direct attention to the factors which have been instrumental in promoting the growing. activity in original investigation during the past twenty years. He will also point out the disadvantages at the present time incidental to university education, and will indicate some of the more important reforms which are required in the immediate future. Other papers which have been arranged for this Section are, bridged rings, by Prof. Perkin; the present position of electrochemical industries in this country and abroad, by Dr. Shields; the chemical exhibits at the Glasgow Exhibition, by Dr. Lewkowitsch; and ocean salt deposits, by Dr. E. F. Armstrong. The last paper may possibly be read at a joint meeting of Sections B and C. Prof. Letts will read papers on the chemical changes which occur during the contact of sewage with "bacteria beds," and on the assimilation of ammonia by the seaweed Ulva latissima.

In addition to Mr. J. Horne's presidential address, on recent advances in Scottish geology, to Section C (Geology), the following papers, among others, will be 
read:-On the volcanic episodes in the geological history of Arran, by Mr. William Gunn; ( $\mathrm{I}$ ) relation of the Old Red Sandstone of north-west Ireland to the Metamorphic rocks, (2) relation of the Silurian and Ordovician rocks of north-west Ireland to the Metamorphic series, by Messrs. A. McHenry and J. R. Kilroe ; on a new method in the investigation of fossil remains, Prof. J. W. Sollas; (I) phosphatic nodules, \&c., in Upper Carboniferous Limestone of west Yorkshire, (2) a silicified plant seam beneath the Millstone Grit of Swarth Fell, by Mr. John Rhodes ; plants and Coleoptera of Pleistocene age from Wolvercote, Oxfordshire, by Mr. A. M. Bell origin of gravel-flats of Surrey and Berkshire, by $\mathrm{Mr}$. $\mathrm{H}$. W. Monckton; (I) the distribution of fishes in the Carboniferous rocks of Scotland, (2) the fish fauna of the Old Red Sandstone of Scotland, by Dr. Traquair, F.R.S. ; the Cambrian fossils of the north-west Highlands, by Mr. B. N. Peach, F.R.S. ; fossil plants from Berwickshire, by Mr. R. Kidston ; sequence of Tertiary igneous rocks of Skye, by Mr. A. Harker; the Scottish ores of copper and their geological relations, by Mr. J. G. Goodchild; recent observations among the volcanic rocks of Mull, by Sir Archibald Geikie ; on Eastern Highland schists, by Mr. G. Barrow; on rock specimens from Perim, by Miss C. A. Raisin.

The address of the president of Section D (Zoology) (Prof. J. Cossar Ewart, F.R.S.), on the experimental study of variation, will be given on Thursday, September I2. The preliminary list of papers to be read shows that from a zoological point of view the Glasgow meeting will be one of exceptional interest ; while the proximity of the Firth of Clyde and the establishment of the marine biological station at Millport will provide attractions of a special character for the marine biologist. The committee have invited lectures from Major Ronald Ross, F.R.S., on tropical parasitology, giving the results of his most recent investigations; and from Dr. J. E. S. Moore, on the problem of Lake Tanganyika. Both gentlemen have consented, subject, in the former case, to Major Ross's expected return from Africa in time. In addition to the above, Prof. J. Arthur Thonson will read a paper on germinal selection in its relation to inheritance; Mr. E. J. Bles, on a method of recording local fauna; Mr. L. A. Borradaile, on the land crabs of Minikoi ; Mr. J. S. Budgett, on the youngest known larva of Polypterus; Mr. J. Graham Kerr, on the origin of vertebrate limbs; Mr. J. Y. Simpson, on variation in relation to binary fission in Protozoa ; and Dr. T. H. Bryce, on heterotypical division in the maturation of sexual cells. These titles indicate the main outlines of the zoological programme, but the committee have not yet finally closed their list. A joint discussion with Sections $\mathrm{C}$ and $\mathrm{E}$ on limnology is provisionally arranged for Monday, September 16 .

In Section E (Geography) the president's address will be delivered on Thursday, September 12, at 10.30 a.m., and will deal specially with the study of geography, as distinct from the teaching of that subject, in this country. Amongst the papers which it is hoped will be communicated to the Section during the meeting are :--Mr. G. G. Chisholm, geographical conditions affecting British trade; Mr. E. G. Ravenstein, Martin Behaim and his globe of 1492 ; Dr. A. J. Herbertson, a morphological map of Europe; Dr. R. Bell (Geological Survey of Canada), Northern Ontario ; Dr. Moreno, on the Argentine Republic; Mr. W. N. Shaw, on weather maps Mr. H. N. Dickson, on mean temperature and glacial periods; Dr. R. Logan Jack, on travels in Western China ; Mr. Yule Oldham, on the Bedford level experiments. Captain Lemaire will give an account of his recent expedition. Special attention will be directed to the geography of Scotland, and it is hoped that Sir A. Geikie will read a paper on some questions relating to this subject; Mr. G. F. Scott Elliott has promised a paper on the effects of vegeNo. I 660, voL. 64] tation in the valley and plains of the Clyde ; Dr. Marion Newbigin, on the proposed survey of the Forth valley, undertaken by the Scottish Natural History Society and Mr. W. G. Smith, on the methods of the Botanical Survey of Scotland inaugurated by his brother, the late Mr. R. A. Smith. Papers will probably be read on the British and German Antarctic expeditions, and $\mathrm{Mr}$. W. S. Bruce has promised a paper on the methods and plans of the Scottish Antarctic Expedition. It is hoped that a joint discussion may be arranged with other sections on the objects and methods of limnology. Sir Thomas Holdich will present the report of the committee on surveys of British Protectorates, and the reports of committees on the climate of Tropical Africa and on surveys of the Phlegræan Fields will also be read.

In Section $G$ (Engineering), the provisional programme includes the following papers :-Address of the president, Colonel R. E. Crompton, on $(a)$ modern development of passenger and goods traffic, as affecting carriage on railways, tramways and ordinary roads ; $(b)$ standardisation and interchangeability; $(c)$ the National Physical Laboratory. Paper by Mr. D. H. Morton on the mechanical exhibits in the Glasgow Exhibition ; report of the conimittee on resistance of road vebicles to traction; the carriage of goods over electric trolley systems, Mr. A. H. Gibbings ; railway rolling stock, present and future, $\mathrm{Mr}$. M. N. Macdonald; the Panama Canal, M. Bunau Varilla; tunnelling through quicksands, M. A. Gobert ; the protection of public buildings from lightning, Mr. Killingworth Hedges; the Diesel engine, Herr Rudolf Diesel; aluminium, Prof. E. Wilson; aluminium as a fuel, Sir W. C. Roberts-Austen, K.C.B., F.R.S. ; report of the committee on the small screw gauge ; recent developments of chain driving, Mr. C. R. Garrard; the critical point in rolled steel joists, Mr. E. T. Edwards ; machinery for engraving, Mr. Mark Barr; measurement of the hardness of materials by indentation by a steel sphere, Mr. T. A. Hearson.

Prof. D. J. Cunnningham, F.R.S., the president of Section $H$ (Anthropology), will take as the subject of his address the human brain, and the part which it has played in the evolution of man ; and papers on physical anthropology are likely to be more prominent this year than on some previous occasions. Special attention will be directed to recent work by Dr. Brown and Mr. Gray on the physical characteristics of the people of Ireland and Scotland respectively; Mr. Douglas, Superintendent of Police at Glasgow, promises an account of the anthropometric method of identification as practised locally ; and other papers on Egyptian and Papuan anthropology are expected from Drs. Rivers and Myers. Two papers have been received on the natives of the Malay Peninsula, by Mr. Skeat, and Messrs. Annandale and Robinson. Dr. Sturge has a paper on the chronology of the Stone Age of man, and Mr. Arthur Evans will supplement the report of the Cretan Exploration Committee by an account of the Neolithic settlement which underlies the great Mycenæan palace of Knossos. Mr. Hogarth also promises an account of this year's campaign in eastern Crete. The report of the Canadian Ethnographic Survey promises, as before, a variety or subjects for discussion; and it is hoped that special arrangements may be made for the description and examination of the ethnographic and archæological sections of the Glasgow Exhibition; though at present the culture and archæology of the neighbourhood remain quite unrepresented in the programme.

The president of Section I. (Prof. J. G. McKendrick, F.R.S.) will open the work of the section with an introductory address. The feature of the transactions will, however, be a discussion on the subject of phonetics. This is to be introduced by a demonstration from the president of the different methods employed in researches into this subject, after which it is expected that Dr. 
Lloyd (Liverpaol), Dr. Pipping (Helsingfors), Dr. Boeke (Alkmaar) and others will take part in the discussion. Communications are also promised from Dr. A. A. Gray (Glasgow), on the cochlea; from Dr. Kennedy (Glasgow), on the repair of nerves ; from Dr. Edridge Green, on the classification of the colour blind ; from Dr. R. Hutchison, on the chemistry of bone marrow. Other contributions are also promised from workers who have not as yet sent in titles. It is not anticipated, however, that the amount of work will be as great as usual, owing to the fact that many British physiologists are attending the International Congress to be held in Turin a week later than the Glasgow meeting.

A discussion on the teaching of botany will be opened in Section $\mathrm{K}$ by $\mathrm{Mr}$. Wager and Prof. Bower from the point of view of school and university teaching respectively. Prof. Miall, Prof. Marshall Ward, Dr. Scott, Prof. Scott-Elliott and others are expected to take part in the discussion. On Friday afternoon, September 13, Prof. Reynolds Green will deliver a semi-popular lecture on flesh-eating plants. The following papers have been promised :- Prof. Bayley Balfour (president), morphological notes; Prof. Marshall Ward, the Bromes and their brown rusts; Mr. Wager, on the cytology of the Cyanophyceæ; Prof. Bower, on an Ophioglossum collected by Mr. Ridley; Dr. Lang, on the prothalli of Helminthostachys, Ophioglossumpendulum and Psilotum; on certain large prothalli of Lycopodium cernuum; on the mode of occurrence of the prothalli of L. Selago at Clova. Mr. Yapp, on two Malayan 'myrmecophilous' ferns; Miss Ford, on the anatomy of Ceratopteris; Mr. Brebner, on the anatomy of Danaea and other Marattiaceæ; Mr. Seward and Miss Ford, on the structure of Todea, and on the geological history of the Osmundacex ; Dr. Scott, on a primitive type of structure in Calamites; Prof. F. W. Oliver, on the structure of certain Palæozoic seeds; Mr. Seward, Jurassic floras; the structure and origin of jet ; Mr. Arber, a collection of fossil plants from New South Wales; Dr. F. F. Blackman and Miss Matthaei, autosurgery in leaves; on respiration; Miss Clark, effect of altered conditions of growth upon Lemna roots; Mr. Tansley, the vegetation of Mount Ophir; Mr. Yapp, some botanical photographs from the Malay Peninsula ; Miss Clark, abnormal secondary thickening in Kendrickia Walkeri; Mr. Worsdell, the structure and morphology of the flowers of Cephalotaxus; the morphology of the ovule; Mr. Tagg, museum work; Mr. Borthwick, increment of wood; Mr. Gwynne-Vaughan, the vascular anatomy of the Cyatheaceæ; on the nature of the stele of Equisetum; Mr. Boodle, remarks on the stele and foliar bundles of ferns.

The new section of Educational Science will be opened on the morning of September 12 with an address by the president, Sir John Gorst. In the afternoon there will be papers and discussions on the organisation of education in Scotland and particularly in Glasgow. On September 13, papers on the science of education will be read by Prof. Armstrong, F.R.S., Prof. Miall, F.R.S., Prof. Withers and others. On Monday, September I6, a discussion on the teaching of mathematics will be introduced by Prof. Perry, F.R.S. On September I7 the subject of discussion will be the influence of universities and examining bodies on the education given in secondary schools, introduced by the Bishop of Hereford and Mr. H. W. Eve

The committee of the Marine Biological Association of the West of Scotland invite members of the Association who are interested in marine biology to work at or visit the Marine Station, Millport, N.B., any time during September IgoI, and to join any of the open collecting excursions of the steam yacht Mermaid during that month. The intention should be communicated to the Curator, Marine Station, Millport, N.B.

NO. I 660 , VOL. 64$]$

\section{THE INTERNATIONAL ZOOLOGICAL CONGRESS.}

THE fifth International Congress, the proceedings of which have just terminated in Berlin, has, notwith. standing the depression caused by the recent death of the Empress Frederick, been a brilliant and important reunion, whether judged by the number and status of the zoologists present or by the interest of its work.

The meetings were held in the Reichstagsgebäude, corresponding to our Houses of Parliament, a fact which in itself testifies to the esteem in which science is held in Germany.

On the evening of Sunday, August II, an informal gathering was held at which the delegates and members were able to meet and greet each other, to renew old acquaintances and form new ones. The business of the Congress began on Monday, August I2, in the large hall of the Reichstag, when Prof. Möbius assumed the presidential chair and, after declaring the proceedings open, made a touching reference to the sorrow which had fallen upon the Royal Family, and proposed that telegrams of condolence should be sent to the Emperor and to the Crown Prince, who had graciously consented to act as patron of the assembly. Replies to these messages were subsequently received and read.

The Congress was then welcomed by $\mathrm{H}$ is Excellency Herr Rothe, Under Secretary of State, in the absence of the Chancellor, by Burgomaster Kirschner and by Prof. Harnack, the Rector of the University. Prof. Perrier expressed the acknowledgments of the foreign delegates, and after some formal business, Prof. Grassi, of Rome, delivered a lecture on "The Malaria Problem from the Zoological Point of View," in which he gave an account of the diseases caused by insect-stings and dwelt upon the importance of their study for the progress of hygiene.

It is usual with us to terminate the proceedings of a congress with a picnic, but the committee charged with the arrangements of the present meeting seem to have thought that the proceedings would be smoother if social intercourse preceded debate, and with this view organised an excufsion to the Havel See.

On the Tuesday no forenoon sittings were held, in consequence of the Royal funeral ; but at midday a general meeting was held, at which, among other business, it was announced that the prize offered by the Emperor Nicholas II. had been awarded to Dr. Oudemans, of Amsterdam, for his memoir "On the Influence of Light on the Development of Colours in the Lepidoptera."

Dr. Sclater having taken the chair, lectures were delivered on "The Theories of Fertilisation," by Prof. Yves Delage (Paris), who referred to the importance of studying the phenomena, not merely morphologically, but also physiologically; and on "The Psychic Faculties of Ants and other Insects," by Prof. Forel (Morges), in which he sought to show an identity between the senses of insects and our own and to demonstrate their possession of memory, association of sensory impressions and power of drawing conclusions from experience.

A general meeting was also held on Thursday afternoon, August 15, when addresses were given by Prof. E. B. Poulton (Oxford) on "Mimicry," by Prof. Patten (Hanover, U.S.A.) on "The Origin of Vertebrates," Prof. v. Zograf (Moscow) on "Hydrobiological Investigations and Institutes in Russia," M. A. Pizon (Paris) on "The Observation of Budding in Tunicates," Mr. C. G. Schillings (Düren) on "East African Mammals," and Mr. O. Neumann on "Results of a Journey from the Red Sea to the White Nile," all illustrated by the lantern.

At other times the Congress separated into seven sections-viz. General Zoology, Experimental Zoology, Vertebrata (Biology, Classification), Vertebrata (Anatomy, 